The Scatter Diagrams published opposite, have been prepared by J. Vlachy, who with his collaborators has made a speciality of such bibliometric studies and has published a number of surveys in the Czechoslovak Journal of Physics.

At the time the study was made, neither the Acta Physica Polonica nor the Journal of Magnetism and Magnetic Materials had yet received the EPS emblem and so are not included. The other Europhysics Journals can be identified from the table below. In interpreting the Diagrams, the following definitions may prove to be of help:

Source Item. Item published in one of the journals processed for the Science Citation Index.

Citation. When one document refers to another, the latter has been cited by the former.

Immediacy Index. Measure of how quickly the average cited article is cited.

Impact Factor. Measure of the frequency with which the average cited article has been cited.

Cited Journal. Journal cited in a reference by a :

Citing Journal.

\section{Europhysics Journals and Publishers}

No. Short Title Publisher

\section{General Physics Journals}

1 Acta Phys. Austriaca Springer Verlag, D

2 Czechoslovak J. Phys. B.Czech. Acad. Sci.

3 Fizika Yugoslav. Acad. Sci.

$4 \mathrm{~J}$. Phys, A: Math. Gen. Inst, of Phys., UK

5 J. Phys. B.: Atom. Inst. of Phys., UK

Molec. Phys.

$6 \mathrm{~J}$. Phys. C.: Solid Inst. of Phys., UK

St. Phys.

7 J. Phys. D.: Appl. Phys. Inst. of Phys., UK

8 J. Phys. E.: Sci. instrum. Inst. of Phys., UK

$9 \mathrm{~J}$. Phys, F: Metal Phys, Inst. of Phys., UK

$10 \mathrm{~J}$. Phys. G.: Nucl. Phys. Inst. of Phys., UK

11 J. Physique Comm. Publ. Phys., F

$12 \mathrm{~J}$. Physique Lett. Comm. Publ. Phys., F

$13 \mathrm{~J}$. Physique Coll. Comm. Publ. Phys., F

14 Nuovo Cim. A Italian Phys. Soc.

15 Nuovo Cim. B Italian Phys. Soc.

17 Physica $A$

18 Physica $B+C$

19 Phys. Scr.

20 Z. Natut. a

21 Z. Phys, A

22 Z. Phys, $B$

34 Acta. Phys, Pol. Specialized Journals

23 Astron. Astrophys.

24 Comput. Phys, Commun North Holland NL

25 Molec. Phys. Taylor \& Francis, UK

26 Nouvelle Revue d'Optique (Appl.)

27 Opta Acta

28 Plasma Phys

29 Revue Phys. Appl.

35 J. Mag. Mag. Mat.

Review Journals

30 Adv. Phys.

31 Contemp. Phys.

32 Phys. Technol.

33 Rep. Prog. Phys.

\title{
European Physics Journals
}

In the constitution of EPS (Article 2), it states that "The purpose of the Society is and shall be to contribute to, and promote, the advancement of physics in Europe and in neighbouring countries by all suitable means". Regular readers of Europhysics News know from its conference lists and reports, that the Society since its inception nearly 10 years ago has been most successful in promoting the advancement of physics in Europe through the coordination of conferences organised by its Divisions and Sections, and sponsored by the So- ciety. In the field of publications it faces a more difficult task, but has made considerable progress through the award of the Europhysics emblem to a set of carefully selected journals. During the past year, the Advisory Committee on Publications has been considering its future policy on the physics journals of Europe and this article explains briefly the lines on which we hope progress can be made during the next decade of the Society.

According to a survey by the Committee of the European Science Re-

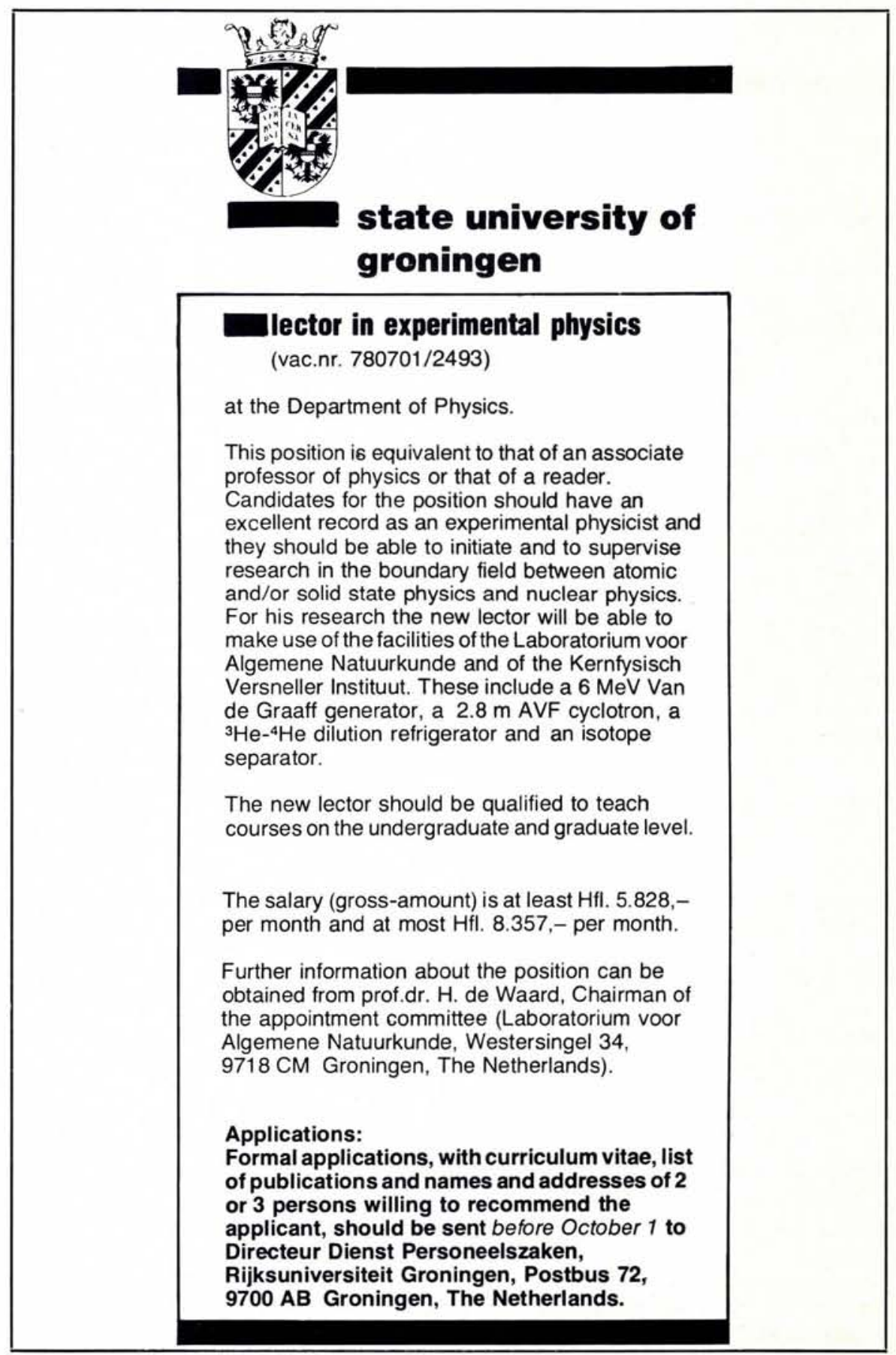


search Councils (ESRC Review No. 8 March 25, 1974) there are about 4600 natural science journals published in Europe and of these 464 are in pure and applied physics. The survey distinguishes between international journals, with a readership all over the world, national journals with a largely country-wide readership, and local journals where the topics and main readership are confined to one district.

It seems that only about $6 \%$ of the natural science journals are truly international, which implies on average about 28 physics titles. They remark that the proliferation of science journals is very obstructive to scientific communication and express the view that the average scientist takes the main part of his information from four or five sources only, mostly large, well reputed journals. In short, we have too many small journals in physics in Europe and as a result their penetration of the world market is weak.

The Publications Committee has to date selected 35 titles for the award of its Europhysics emblem which shows that these journals are recognized as having a European Board of Editors, a high standard of refereeing and a wide circulation. The titles are in three categories: general physics journals, specialist journals and review journals. Through the EPS Divisions and Sections, EPS members are encouraged to publish in the Europhysics journals and to recommend them to their institutional libraries. In this way, considerable progress has been made in establishing the Europhysics journals throughout Europe. Their international penetration has also increased, but is still typically only $30-40 \%$ of the potential readership market. As a consequence, some of the most exciting and important physics research in Europe is not published in European journals, but in the journals of the American Institute of Physics, notably Physical Review and Physical Review Letters.

At the recent EPS meeting in $\mathrm{Hel}-$ sinki, the Council agreed that the future publication policy of the Society was to promote a single, coherent set of general, specialist and review journals containing between 10 and 15 titles, as being advantageous from both the scientific and economic points of view. A unified, coherent set of titles would ensure that the articles published therein were accessible to nearly all readers, because all institutions with physicists should be able to purchase the titles relevant to their own work. The result is that a unified or amalgamated sys-

\section{Johann Wolfgang Goethe-Universität Frankfurt a.M.}

An der Universität Frankfurt a.M. ist folgende Hochschullehrerstelle zu besetzen :

im Fachbereich Physik: (am Institut für Theoretische Physik)

die Stelle eines Professors (H3) für Theoretische Physik.

Der Stelleninhaber soll am Lehr- und Ausbildungsprogramm der Theoretischen Physik mitarbeiten. Von den Bewerbern wird neben Lehrerfahrung in Theoretischer Physik Forschungsaktivität auf dem Gebiet der Feldtheorie und ihrer Anwendungen (Elementarteilchenphysik, Astrophysik usw.) erwartet. Die Bereitschaft zur Zusammenarbeit mit bestehenden Gruppen ist erwünscht.

Für die Ernennung zum Hochschullehrer sind grundsätzlich pädagogische Eignung und - als Nachweis der Befähigung zu wissenschaftlicher Arbeit - eine Promotion und hervorragende weitere wissenschaftliche Leistungen erforderlich (§ 39a HUG). Im übrigen gelten die Einstellungsvoraussetzungen des § 39 HUG (Textauszug wird auf Anforderung übersandt).

Von den Bewerbern wird erwartet, dass sie im Falle ihrer Berufung gemäss $\S 39$ HUG ihr Fach in Lehre und Forschung selbständig vertreten und sich an der Selbstverwaltung der Universität beteiligen.

Bewerbungen mit Lebenslauf (wissenschaftlicher und beruflicher Werdegang), Fotokopie der Promotionsurkunde, Verzeichnis der selbständig durchgeführten Lehrveranstaltungen und Schriftenverzeichnis (bei gemeinschaftlichen Veröffentlichungen soll der Bewerber vermerken, worin seine Miturheberschaft besteht) werden bis zum 15.10.1978, an den Präsidenten der Universität, Senckenberganlage 31, 6000 Frankfurt am Main erbeten.

tem would provide much better communication of scientific research results between European countries and from European laboratories to the rest of the world. We could then expect to see again the most important results of the research of European physicists being published by Europeans in Europe, as they were in the early years of this century.

The multiplicity of titles in existence at the moment means that many journals sell too few copies to be economic and have to be subsidised. A unified set of titles should lead to longer runs for the amalgamated journals and so a cheaper cost per page. This economic advantage can then be used to reduce or eliminate the subsidies, to enable EPS members to purchase personal copies at much reduced prices and to lower the total purchase price to libraries.

Now that the Society has recovered from its financial difficulties, it is possible to consider new initiatives in the publications sector and Council approved the principle that EPS become actively involved in the establishment of this unified, coherent set of titles in consultation with the national societies and commercial publishers. This is a worthy programme for the second decade of the Society and one that the Publications Committee will wish to fulfill, with the aid of the Divisions and Sections. To consider the ways and means for assisting future developments in the publications field, the Executive Committee has established a Study Group under the chairmanship of M. Guenin, its present secretary, and it is hoped that further details of the proposed policy will be agreed at the EPS Council meeting at York in September.

Meanwhile, the Publications Committee will no longer consider any new applications for the Europhysics emblem, although it will process two further applications that were received in 1977. These are for specialist journals in the fields of acoustics and electronics. If implementation of the new policy is successful, it is likely that some of the Europhysics journals will soon be amalgamated to form sections of the new, coherent set, while others will remain as Europhysics journals for much longer. The coherent set is unlikely to be fully established before 1985, so the emblem will continue for most of the next decade and indeed may not have been withdrawn at the end. As EPS has limited financial resources, any new titles that are launched are likely to be joint ventures with one of the existing publishers of Europhysics journals. (One possibility is already under discussion as a joint publication with a national society).

So much for the general policy. There is evidently much to be done in deciding how best a given field of physics can be served and how best existing titles can be merged or replaced. All suggestions from members for a rationalization of publications in their own sector would be welcome. They should be sent to the Executive Secretary in Geneva.

E.R. Dobbs 